\title{
Transport and Hydrolysis of Peptides in Saccharomyces cerevisiae
}

\author{
By PHILIPPE MONETON, PIERRE SARTHOU* AND \\ FRANCOIS LE GOFFIC \\ CNRS-CERCOA, 2 rue Henry Dunant, 94320 Thiais, France
}

(Received 29 July 1985; revised 13 March 1986)

\begin{abstract}
The transport and hydrolysis of several radioactive di- and tripeptides in Saccharomyces cerevisiae was studied. A peptide-transport-deficient mutant isolated on the basis of its resistance to nikkomycin $Z$ lost most of its capacity to take up di- and tripeptides. The transport kinetics of $\left[{ }^{14} \mathrm{C}\right]$ methionylglycine, $\left[{ }^{14} \mathrm{C}\right]$ methionylsarcosine and $\left[{ }^{3} \mathrm{H}\right]$ nikkomycin $\mathrm{Z}$ indicated that peptide transport is not dependent on intracellular hydrolysis. Intact cells had some peptidase activity towards methionylsarcosine but not towards nikkomycin $Z$. The relationship between this activity and peptide transport is discussed.
\end{abstract}

\section{INTRODUCTION}

The yeast Saccharomyces cerevisiae can take up various peptides through active transport systems (Becker \& Naider, 1980). Marder et al. (1978) and Nisbet \& Payne (1979a) demonstrated that di- and tripeptides share a common transport system in this yeast. Several studies have established that peptides are not hydrolysed by extracellular peptidases before transport (Naider et al., 1974; Marder et al., 1977; Parker et al., 1980). However, little is known about the contribution of membrane-bound or cytoplasmic peptidases to the overall activity of the peptide transport systems. Nisbet \& Payne (1979 b) demonstrated the accumulation of intact (non-hydrolysable) sarcosine peptides in S. cerevisiae. In a recent study (Yadan et al., 1984) we showed that the pathogenic yeast Candida albicans accumulated the toxic dipeptide nikkomycin $\mathrm{Z}$ via a peptide transport system(s). This non-hydrolysable peptide had a high affinity for the transport system but a very low maximal rate of entry when compared with di- and trimethionine. In this paper we report results concerning the uptake and hydrolysis of several radioactive di- and tripeptides in $S$. cerevisiae. We show that both $K_{\mathrm{m}}$ and $V_{\max }$ for transport are independent of the hydrolysable nature of the peptides studied. In addition,, our data provide evidence that $S$. cerevisiae can hydrolyse a sarcosyl peptide after transport into the cell. The role and the nature of peptidases involved in this process are discussed.

\section{METHODS}

Organism and growth conditions. Saccharomyces cerevisiae ATCC 9896 was cultivated at $30^{\circ} \mathrm{C}$ to early exponential phase in the minimal medium YNB without amino acids and $\mathrm{NH}_{4}^{+}$(Difco 0.335-15) $\left(1 \cdot 7 \mathrm{~g}^{-1}\right.$ ), leucine $\left(4.5 \mathrm{~g} \mathrm{l}^{-1}\right)$ and glucose $(2 \%, \mathrm{w} / \mathrm{v})$. Cells were harvested by centrifugation, washed with cold $0 \cdot 05 \mathrm{M}-\mathrm{KH}_{2} \mathrm{PO}_{4} / \mathrm{K}_{2} \mathrm{HPO}_{4}$ buffer, pH 5.5, and resuspended in the same buffer supplemented with $2 \%(\mathrm{w} / \mathrm{v})$ glucose (buffer A).

Transport studies. Suspensions of cells in buffer A were incubated with stirring at $30{ }^{\circ} \mathrm{C}$ for 15 min; radioactive peptides were then added. Samples $(0.5 \mathrm{ml})$ were removed at $15 \mathrm{~s}$ intervals over a period of $1 \mathrm{~min}$, filtered on $0.45 \mu \mathrm{m}$ pore size Millipore filters and washed twice with $5 \mathrm{ml}$ of cold buffer A. The filters were dried and placed in $10 \mathrm{ml}$ Bray's solution; the radioactivity was measured in a Kontron MR 300 scintillation spectrometer. Initial rates of uptake were determined in triplicate. Mean values were expressed as pmol peptide transported min ${ }^{-1}$ normalized to a cell density of 1 Klett unit $\left(6 \times 10^{4}\right.$ cells ml-1). SD values of separate measurements did not exceed $10 \%$ of the mean value.

Abbreviation: BOC, $t$-butyloxycarbonyl. 
Peptidase assays. Cells were grown, harvested and washed as described above. Peptidase activities were then assayed in cell-free extracts (method $a$ ) and in intact cells (method $b$ ).

Method (a). After resuspension in buffer A to a final volume corresponding to a hundredfold concentration of cells, an identical volume of glass beads was added. The cells were disrupted with cooling in a Braun MSK homogenizer, and centrifuged to remove glass beads and unbroken cells. The supernatant extract was then appropriately diluted with buffer $\mathrm{A}$ and tested for peptidase activity: after $10 \mathrm{~min}$ incubation at $30^{\circ} \mathrm{C}$, radioactive peptide samples were added to the supernatant solution and $50 \mu \mathrm{l} \mathrm{samples}$ were removed at $0.5,2$ and $30 \mathrm{~min}$. After dilution in a small volume of cold ethanol, the samples $(100 \mu \mathrm{l})$ were applied to silica gel plates for separation by TLC. After running with butanol/acetic acid/water $(4: 1: 1$, by vol.), the plates were dried and scanned for radioactivity. The hydrolysis products were compared with radioactive or non-radioactive amino acid control samples chromatographed under the same conditions.

Method $(b)$. Suspensions of cells in buffer A $\left(8 \times 10^{7}\right.$ cells $\left.\mathrm{ml}^{-1}\right)$ were incubated with stirring at $30^{\circ} \mathrm{C}$ for $15 \mathrm{~min}$; radioactive peptides were then added. At $15 \mathrm{~s}, 1 \mathrm{~min}, 2 \mathrm{~min}, 5 \mathrm{~min}, 15 \mathrm{~min}$ and $30 \mathrm{~min}, 0.5 \mathrm{ml}$ samples were removed, centrifuged at $9800 G$ for $30 \mathrm{~s}$ and washed twice in cold buffer $A$. The cells were then disrupted with glass beads and cell extracts were analysed for peptides and hydrolysed residues as described in method (a). Mean values were calculated from three separate experiments.

Measurement of protein synthesis. Cells were grown and harvested as described above. After washing, the cells were resuspended in the minimal (leucine) medium in a final volume corresponding to a tenfold concentration of cells. The suspensions were then incubated with stirring for $15 \mathrm{~min}$ at $30^{\circ} \mathrm{C}$ with or without cycloheximide $\left(10 \mu \mathrm{g} \mathrm{ml}^{-1}\right) .{ }^{35} \mathrm{~S}$-labelled peptides (see below) were then added and, at various intervals, $0.5 \mathrm{ml}$ samples were filtered, washed and counted as described above, to measure the total radioactivity incorporated. Simultaneously, another $0.5 \mathrm{ml}$ sample was diluted in the same volume of cold $20 \%(\mathrm{w} / \mathrm{v}) \mathrm{TCA}$, held at $0{ }^{\circ} \mathrm{C}$ for $10 \mathrm{~min}$, and then heated in boiling water for $15 \mathrm{~min}$. After rapid cooling, the precipitate was collected by filtration and washed with $10 \%(\mathrm{w} / \mathrm{v})$ TCA. The filters were dried and counted as described above. Mean values were calculated from three separate experiments.

Isolation of a nikkomycin Z-resistant, peptide-transport-deficient mutant. Spontaneous nikkomycin Z-resistant (Nik) mutants of S. cerevisiae ATCC 9896 were isolated as described by Yadan et al. (1984) for C. albicans, except that the cells were grown in the minimal (leucine) medium described above.

Synthesis of radioactive peptides. The synthesis of $\mathrm{L}-\left[\right.$ methyl- $\left.{ }^{14} \mathrm{C}\right]$ methionyl-L-methionine, $\mathrm{L}-[$ methyl-14 $\mathrm{C}] \mathrm{meth}-$ ionyl-L-methionyl-L-methionine and $\left[{ }^{3} \mathrm{H}\right]$ nikkomycin $\mathrm{Z}$ were described by Yadan et al. (1984). L- $[$ methyl-14 $\mathrm{C}]-$ Methionylglycine, $\mathrm{L}-\left[{ }^{35} \mathrm{~S}\right]$ methionylglycine, $\mathrm{L}-\left[\right.$ methyl $\left.-{ }^{14} \mathrm{C}\right]$ methionylsarcosine and $\mathrm{L}-\left[{ }^{55} \mathrm{~S}\right]$ methionylsarcosine were prepared essentially as described above using either BOC- $\left[{ }^{14} \mathrm{C}\right]$ or BOC- $\left[{ }^{35} \mathrm{~S}\right]$ methionyl succinimide coupling to glycine and sarcosine respectively. After deprotection, the radioactive dipeptides were purified by TLC and HPLC. All peptides were shown to be homogeneous by these methods.

\section{RESULTS}

\section{Isolation of a peptide-transport-deficient mutant}

Nikkomycin $Z$ is a potent inhibitor of chitin synthase in yeast (Adams \& Gooday, 1983). We (Yadan et al., 1984) and others (McCarthy et al., 1985) have demonstrated that in C. albicans this nucleosidyl dipeptide antibiotic exerts its toxicity after entry into the cell through peptide transport systems. In the present work, we isolated a spontaneous peptide-transport-deficient mutant of $S$. cerevisiae ATCC 9896 on the basis of its resistance to nikkomycin Z as previously described for $C$. albicans (Yadan et al., 1984). This Nik mutant was totally resistant to concentrations of nikkomycin $\mathrm{Z}$ up to $400 \mu \mathrm{g} \mathrm{ml}^{-1}$, as compared with the wild-type which is sensitive to $6 \mu \mathrm{g} \mathrm{ml}^{-1}$. The sensitivity of $S$. cerevisiae to nikkomycin $Z$ was highly mediumdependent. The wild-type was insensitive to the drug in a peptone-rich (YEPG) medium in contrast to C. albicans (Yadan et al., 1984). Becker \& Naider (1977) reported that the rates of uptake of peptides for $S$. cerevisiae ATCC 9896 grown on proline were greater than for cells grown on $\mathrm{NH}_{4}^{+}$as nitrogen source. We observed that this strain was more sensitive to toxic peptides when proline was replaced by leucine, and that this could be correlated with an increase in peptide uptake rates (not shown). We therefore isolated the Nik mutant from cells grown in leucine minimal medium and did all further experiments using the same medium.

\section{Transport of peptides}

We synthesized several ${ }^{14} \mathrm{C}$-labelled di- and tripeptides and measured their rates of uptake in wild-type S. cerevisiae ATCC 9896 and in the Nik mutant. The transport of these di- and 


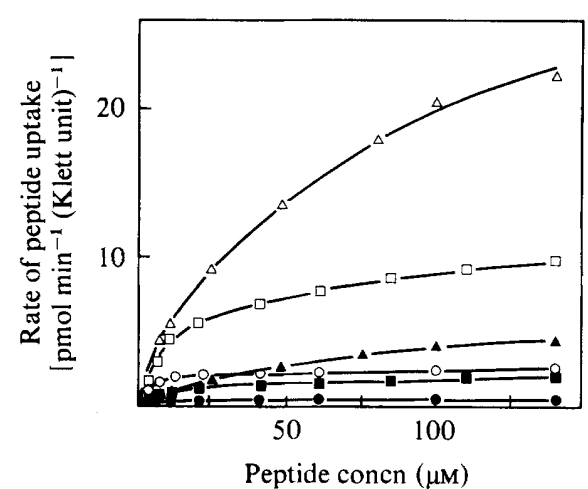

Fig. 1

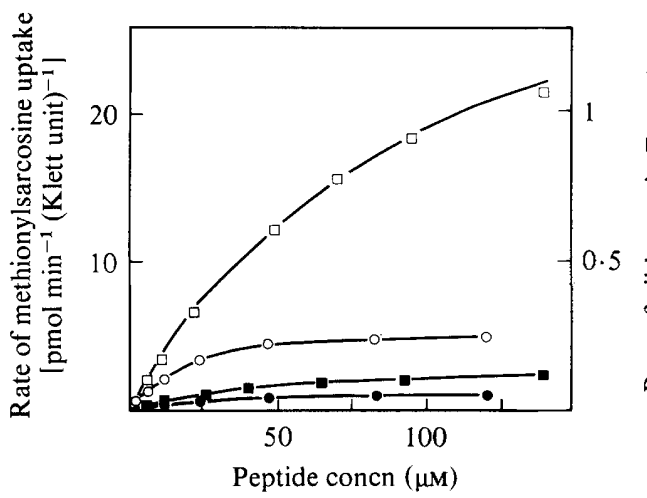

Fig. 2

Fig. 1. Effect of external substrate concentration on the initial rate of peptide uptake in $S$. cerevisiae ATCC 9896 wild-type $(\triangle, \square, 0)$ and in the Nik mutant $(\Delta, \square, \bigcirc) . \triangle, \Delta,\left[{ }^{14} C\right]$ Methionylglycine; $\square$, D, $\left[{ }^{14} \mathrm{C}\right]$ dimethionine; $O$, $O,\left[{ }^{14} \mathrm{C}\right]$ trimethionine.

Fig. 2. Effect of external substrate concentration on the initial rate of peptide uptake in $S$. cerevisiae ATCE 9896 wild-type $(\square, \bigcirc)$ and in the $\operatorname{Nik}$ mutant $(\square, O) . \square, \square,\left[{ }^{14} \mathrm{C}\right]$ Methionylsarcosine; $\bigcirc, O$, $\left[{ }^{3} \mathrm{H}\right]$ nikkomycin $\mathrm{Z}$.

\section{Table 1. Transport of radioactive peptides and methionine in S. cerevisiae}

Cells were grown in minimal (leucine) medium, harvested, washed and resuspended in glucosepotassium phosphate buffer $\mathrm{pH} 5.5$ at $30^{\circ} \mathrm{C} . K_{\mathrm{m}}\left(10^{-5} \mathrm{M}\right)$ and $V_{\max }$ [pmol $\min ^{-1}$ (Klett unit) $)^{-1}$ ] values were calculated from Lineweaver-Burk plots.

\section{Peptide or amino acid}

$\left[{ }^{14} \mathrm{C}\right]$ Trimethionine

$\left[{ }^{14} \mathrm{C}\right]$ Dimethionine

$\left[{ }^{14} \mathrm{C}\right]$ Methionylglycine

$\left[{ }^{14} \mathrm{C}\right]$ Methionylsarcosine

$\left[{ }^{3} \mathrm{H}\right]$ Nikkomycin Z

$\left[{ }^{14} \mathrm{C}\right]$ Methionine

\begin{tabular}{lcc}
\multicolumn{3}{c}{ Wild-type } \\
$\boldsymbol{K}_{\mathrm{m}}$ & $V_{\max }$ & $V_{\max } / K_{\mathrm{m}}$ \\
0.4 & 2.5 & 62.5 \\
1.4 & 10 & 71.4 \\
4.4 & 25.5 & 58 \\
7.3 & 31 & 42.4 \\
2 & 0.3 & 1.5 \\
2.8 & 13 & 46.4
\end{tabular}

tripeptides was saturable (Figs 1 and 2). The apparent affinities for the methionyl peptides increased in the order methionylsarcosine $<$ methionylglycine $<$ dimethionine $<$ trimethionine as shown in Table $1\left(K_{\mathrm{m}}\right.$ values). Trimethionine uptake in the wild-type had a $K_{\mathrm{m}}$ value $\left(0.4 \times 10^{-5} \mathrm{M}\right.$, Table 1) almost twentyfold lower than the $K_{\mathrm{m}}$ value $\left(7 \cdot 7 \times 10^{-5} \mathrm{M}\right)$ calculated by Becker \& Naider (1977) for the same strain. This discrepancy may be related to the different source of nitrogen we used for cell growth (i.e. leucine instead of proline) as described above. Interestingly, the maximal rates of transport ( $V_{\max }$ values) varied in the opposite order: trimethionine $<$ dimethionine $<$ methionylglycine $<$ methionylsarcosine (Table 1 ). If one calculates $V_{\max }$ versus $K_{\mathrm{m}}$ ratios (Table 1) it is evident that the methionyl peptides are transported to a similar extent irrespective of their structure. We thus believe that these ratios are a better estimate of peptide transport efficiencies than are $K_{\mathrm{m}}$ values. In comparison, the transport of $\left[{ }^{3} \mathrm{H}\right]$ nikkomycin $\mathrm{Z}$ was saturable and had a $K_{\mathrm{m}}$ value comparable with those of the methionyl dipeptides tested above. However, the maximal rate of entry $\left(V_{\max }\right)$ was considerably lower than the other $V_{\max }$ values. These observations extend previous results from this laboratory concerning the uptake of nikkomycin $\mathrm{Z}$ in C. albicans (Yadan et al., 1984).

The Nik mutant had lost most of its capacity to transport both di- and tripeptides (Figs 1 and 2, Table 1). This observation is in line with the findings of Marder et al. (1978) and Nisbet \& Payne (1979a) on different strains of $S$. cerevisiae. Our data also indicate that the loss of peptide transport ability was probably due to a decrease in the total number of carriers (decreased $V_{\max }$ 


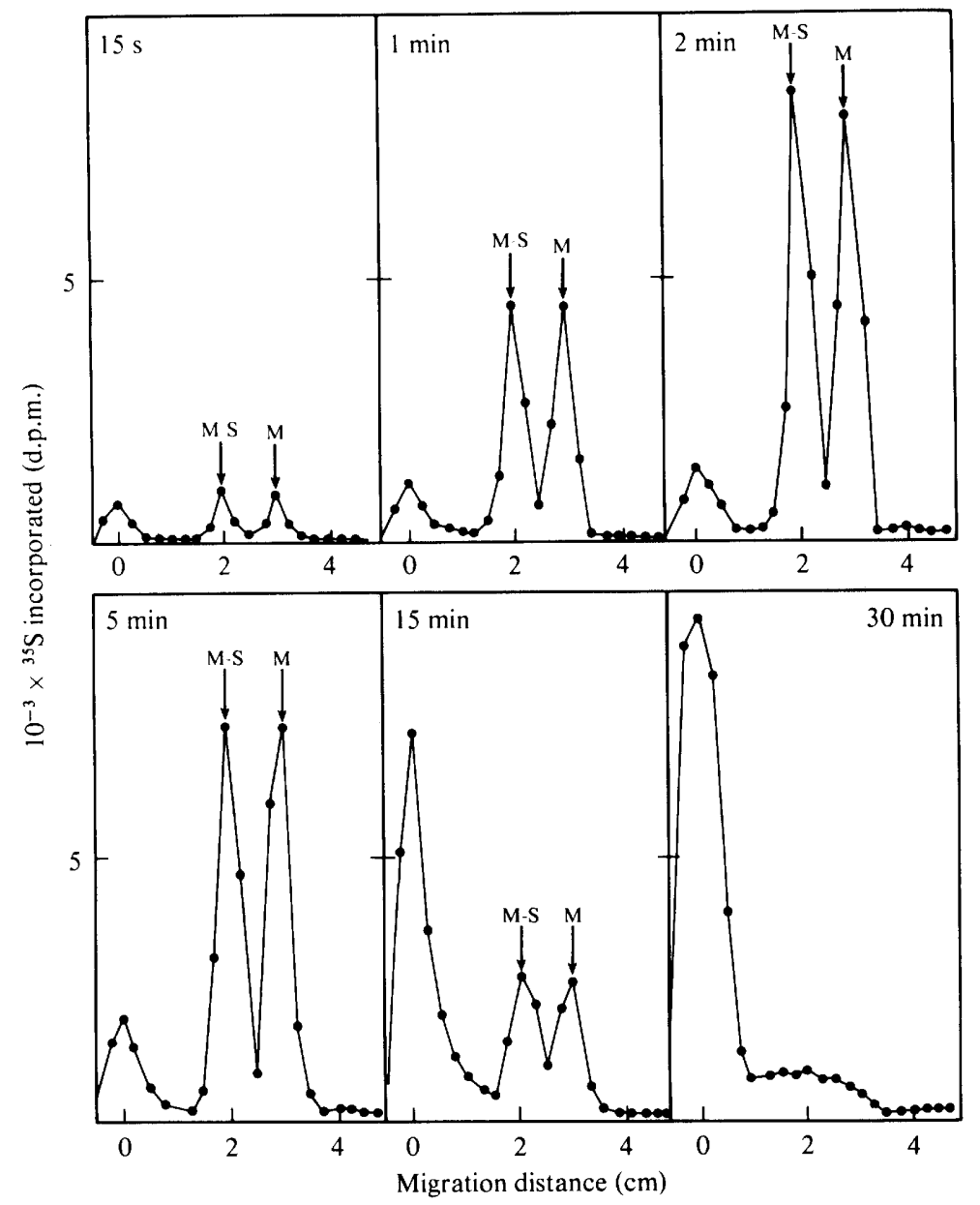

Fig. 3. Kinetics of $\left[{ }^{35}\right.$ S $]$ methionylsarcosine metabolism. S. cerevisiae ATCC 9896 wild-type was incubated with $\left.{ }^{35} \mathrm{~S}\right]$ methionylsarcosine $\left[8 \times 10^{-5} \mathrm{M}, 4 \mathrm{Ci} \mathrm{mol}^{-1}\left(148 \mathrm{GBq} \mathrm{mol}^{-1}\right)\right]$ for various lengths of time; the radioactive content of the cells was then analysed by TLC (see Methods). Thin layer chromatograms were cut into strips and each strip was counted by liquid scintillation. Methionylsarcosine (M-S) and methionine (M) markers are indicated on each chromatogram.

values, Table 1) rather than to a decrease in affinity (similar $K_{\mathrm{m}}$ values, Table 1). Finally, methionine transport was unaffected in the Nik mutant as compared with the wild-type (Table 1). This observation confirms previous work demonstrating that amino acids and peptides use different uptake systems (Becker \& Naider, 1980).

\section{Hydrolysis of peptides}

Certain peptides containing sarcosine residues have been previously reported to be accumulated intact in $S$. cerevisiae (Nisbet \& Payne, 1979b). Naider et al. (1983) demonstrated that polyoxin $\mathrm{D}$, an antifungal agent closely related to nikkomycin $\mathrm{Z}$, was resistant to hydrolysis after transport in $C$. albicans. We therefore investigated whether methionylsarcosine and nikkomycin $Z$ were resistant to enzymic hydrolysis. The ability of cell-free extracts to cleave radioactive di- and tripeptides was determined first. Methionylglycine, dimethionine and trimethionine were totally hydrolysed in less than $30 \mathrm{~s}$. In contrast, methionylsarcosine and nikkomycin $\mathrm{Z}$ were resistant to enzymic cleavage even after $30 \mathrm{~min}$ incubation (data not shown). These results are an estimate of the peptidase activity present in the soluble fraction but 


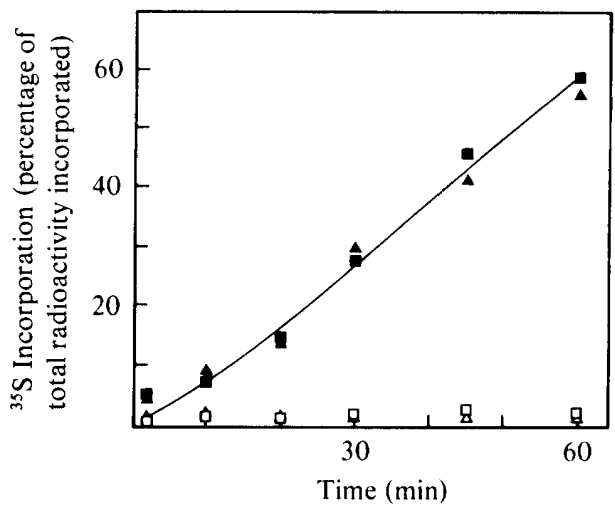

Fig. 4. Incorporation of ${ }^{35} \mathrm{~S}$ into TCA-precipitable material. $S$. cerevisiae ATCC 9896 wild-type was incubated with either $\left[{ }^{35} S\right]$ methionylglycine $(\triangle, \Delta)$ or $\left[{ }^{35} S\right]$ methionylsarcosine $(\square, \square)\left[4 \times 10^{-5} \mathrm{M}\right.$, $\left.4 \mathrm{Ci} \mathrm{mol}^{-1}\left(148 \mathrm{GBq} \mathrm{mol}^{-1}\right)\right]$. Samples were removed at timed intervals and the radioactive content of the TCA-precipitable material was measured and compared with the total amount of radioactivity incorporated. $\triangle, \square,+$ Cycloheximide $\left(10 \mu \mathrm{g} \mathrm{ml}^{-1}\right) ; \Delta, \square,-$ cycloheximide.

do not indicate if a membrane-bound peptidase activity is involved in intact cells. We therefore tested the ability of intact cells to hydrolyse peptides after transport. Again methionylglycine, dimethionine and trimethionine were totally hydrolysed in less than $15 \mathrm{~s}$ whereas nikkomycin $\mathrm{Z}$ was accumulated intact over a $30 \mathrm{~min}$ period (data not shown). Surprisingly, methionylsarcosine was partially hydrolysed under the same conditions. The data in Fig. 3 show that within $15 \mathrm{~s}$ part of the radioactivity moved as a peak which had the same mobility as methionine. The ratio methionylsarcosine versus methionine remained constant over a period of $15 \mathrm{~min}$. However, after $2 \mathrm{~min}$ the total radioactivity recovered from the methionylsarcosine plus methionine fractions decreased in parallel with an increase of radioactivity at the origin of migration. Similar studies on the Nik mutant led to essentially the same conclusions, although the amount of radioactivity incorporated was much lower than for the wild-type as expected for a peptidetransport-deficient mutant (data not shown). Together with the data in Table 1 this also indicates that external hydrolysis of methionylsarcosine before transport is unlikely, since the Nik mutant normally retained its capacity to take up methionine.

We next examined whether $\left[{ }^{35}\right.$ S]methionylsarcosine could serve as a precursor of $\left[{ }^{35} \mathrm{~S}\right]$ methionine for protein synthesis. Fig. 4 shows that this was indeed the case since comparable amounts of radioactivity were incorporated into TCA-precipitable material from either ${ }^{35} \mathrm{~S}$-labelled methionylsarcosine or methionylglycine. Cycloheximide $\left(10 \mu \mathrm{g} \mathrm{ml}^{-1}\right)$ totally abrogated ${ }^{35} \mathrm{~S}$ incorporation into TCA-precipitable material (Fig. 4) but did not modify the rate of entry of the two dipeptides (not shown). Taken together, these results demonstrate that intact $S$. cerevisiae cells can hydrolyse a sarcosyl peptide, in contrast to earlier reports (Nisbet \& Payne, $1979 \mathrm{~b}$ ). However, only part of this unusual peptide is broken down under these conditions and a transient accumulation of methionylsarcosine can be detected.

\section{DISCUSSION}

The results presented here demonstrate that $S$. cerevisiae can take up various di- and tripeptides through a single transport system. In contrast, we previously showed that $C$. albicans transports peptides through multiple systems with partial overlapping specificities (Sarthou et al., 1983; Yadan et al., 1984). We have isolated a peptide-transport-deficient (Nik) mutant of $S$. cerevisiae ATCC 9896 on the basis of its resistance to nikkomycin Z, a potent inhibitor of chitin synthase. This mutant has lost both di-and tripeptide transport ability. This observation is again in contrast to our previous findings concerning a $C$. albicans Nik mutant which had lost dipeptide transport but had simultaneously increased its capacity to take up tripeptides (Yadan 
et al., 1984). Our results provide further support for the view (Nisbet \& Payne, 1979b) that peptide uptake in $S$. cerevisiae is not strictly dependent on peptidase activity. Nikkomycin $Z$ is a nucleosidyl dipeptide antifungal agent of natural origin (Adams \& Gooday, 1983). It exerts its toxicity only in its intact form and it is resistant to enzymic cleavage. This study demonstrates that nikkomycin $\mathrm{Z}$ is transported into $S$. cerevisiae through the general peptide transport system described above. The apparent affinity $\left(K_{\mathrm{m}}\right)$ of nikkomycin $\mathbf{Z}$ for this system is high but the initial rates of entry $\left(V_{\max }\right)$ are very low compared to the other dipeptides tested. These observations are consistent with previous results from this laboratory on the uptake of nikkomycin $\mathrm{Z}$ in C. albicans (Yadan et al., 1984). Finally, as expected from previous reports (Adams \& Gooday, 1983; Naider et al., 1983), we could not demonstrate any peptidase activity towards nikkomycin $Z$, either in cell-free extracts or intact cells.

The kinetic characteristics of methionylsarcosine transport were very similar to those of the non-methylated analogue methionylglycine. Using cell-free extracts, we could not detect any peptidase activity towards methionylsarcosine under conditions where methionylglycine and diand trimethionine were rapidly and totally hydrolysed. These findings indicate either that the soluble fraction is devoid of peptidase activity towards methionylsarcosine, or alternatively that enzymic cleavage of methionylsarcosine may require an essential cofactor which was not provided in our assay mixture. In any case, our observations provide evidence for major differences in soluble peptidase activities towards peptides with unsubstituted or substituted peptide-bonds. In contrast, intact cells were able to hydrolyse methionylsarcosine after transport. About $50 \%$ of the peptide was cleaved within the first $15 \mathrm{~s}$. The remaining intact peptide was then totally metabolized, together with methionine, over a much longer period during which net peptide accumulation stopped. Most of the radioactivity contained in the methionylsarcosine plus methionine fractions was recovered in a slow moving peak on TLC. Newly synthesized proteins (see Fig. 4) were probably contained in this peak. When cells were preloaded with radioactive methionylsarcosine there was no detectable release of radioactive material into the external medium (not shown). This observation, which extends the findings of Nisbet \& Payne (1979b) using a different assay system, further supports the view that most (if not all) of the methionine content of the transported methionylsarcosine is incorporated into proteins. Taken together, these data indicate that $S$. cerevisiae can take up and metabolize a sarcosylpeptide. On the other hand, Nisbet \& Payne $(1979 b)$ showed that this yeast accumulated other sarcosyl peptides in an intact form. This apparent discrepancy might be explained by the different strains and/or the different sarcosylpeptides used in these studies.

Much remains to be done in order to establish the precise mechanism by which $S$. cerevisiae hydrolyses the unusual peptide bond of methionylsarcosine. Based upon the current results, it appears that soluble enzymic activities display significant differences towards usual and unusual peptide bonds. The origins of these differences and the possible occurrence of membrane-bound peptidase activities are currently under investigation in our laboratory.

\section{REFERENCES}

ADAMS, D. J. \& GoOdAY, G. W. (1983). Chitin synthesis as a target. Abhandlungen der Akademie der Wissenschaften der DDR 1N, 39-45.

BeCKER, J. M. \& NAIDER, F. (1977). Peptide transport in yeast: uptake of radioactive trimethionine in Saccharomyces cerevisiae. Archives of Biochemistry and Biophysics 178, 245-255.

BeCKer, J. M. \& NAIDER, F. (1980). Transport and utilization of peptides by yeast. In Microorganisms and Nitrogen Sources, pp. 257-279. Edited by J. W. Payne. Chichester: John Wiley.

McCarthy, P. J., Troke, P. F. \& Gull, K. (1985). Mechanism of action of nikkomycin and the peptide transport system of Candida albicans. Journal of General Microbiology 131, 775-780.
MARDER, R., Becker, J. M. \& NAIDER, F. (1977). Peptide transport in yeast: utilization of leucine- and lysine-containing peptides by Saccharomyces cerevisiae. Journal of Bacteriology 131, 906-916.

MARDER, R., ROSE, B., BECKer, J. M. \& NAIDER, F. (1978). Isolation of a peptide transport-deficient mutant of yeast. Journal of Bacteriology 136, 11741177.

NAIDER, F., BeCKer, J. M. \& KatZIR-KatChaLSKy, E. (1974). Utilization of methionine-containing peptides and their derivatives by a methionine-requiring auxotroph of Saccharomyces cerevisiae. Journal of Biological Chemistry 249, 9-20.

Naider, F., Shenbagamurthi, P., Steinfeld, A. S., SMITH, H. A., BONEY, C. \& BECKER, J. M. (1983). 
Synthesis and biological activity of tripeptidylpolyoxins as antifungal agents. Antimicrobial Agents and Chemotherapy 24, 787-796.

Nisbet, T. M. \& PAYNe, J. W. (1979a). Specificity of peptide uptake in Saccharomyces cerevisiae and isolation of a bacilysin-resistant, peptide-transportdeficient mutant. FEMS Microbiology Letters 6, 193196.

Nisbet, T. M. \& PAYNe, J. W. (1979b). Peptide uptake in Saccharomyces cerevisiae: characteristics of a transport system shared by di- and tripeptides. Journal of General Microbiology 115, 127-133.
Parker, D. D., Naider, F. \& Becker, J. M. (1980). Separation of peptide transport and hydrolysis in trimethionine uptake by Saccharomyces cerevisiae. Journal of Bacteriology 143, 1066-1069.

Sarthou, P., Gonneau, M. \& Le Goffic, F. (1983). Photoaffinity inhibition of peptide transport in yeast. Biochemical and Biophysical Research Communications 110, 884-889.

Yadan, J. C., Gonneau, M., SArthou, P. \& LE GofFIC, F. (1984). Sensitivity to nikkomycin Z in Candida albicans: role of peptide permeases. Journal of Bacteriology 160, 884-888. 